\title{
EFFECT OF SEASON AND FREEZING ON SPERM VELOCITY, PLASMA MEMBRANE INTEGRITY AND ACROSOMAL STATUS OF EGYPTIAN BUFFALOES SPERMATOZOA
}

\author{
Sh. M. Dessouki ${ }^{1}$, G. Ashour ${ }^{1}$, A. M. Hassanein ${ }^{2}$ and A. H. Barkawi ${ }^{1}$ \\ 1- Department of Animal Production, Faculty of Agriculture, University of Cairo, \\ 12613, Giza, Egypt, 2- Department of Animal Production, Faculty of Agriculture, \\ University of Suez Canal, Ismailia, Egypt
}

\section{SUMMARY}

This work aimed at studying the impact of season of the year and cryopreservation process on the spermatozoa characteristics of the Egyptian buffalo bulls. Year was divided into two periods; cold (September - March) and hot (April August). Semen was collected from six intact buffalo bulls twice weekly. One hundred - 40 outstanding semen samples representing two periods of the year were used. Semen was diluted using Tris-based extender and stored in French straws $(0.25 \mathrm{ml})$. Semen straws were frozen in liquid nitrogen. Characteristics of spermatozoa motion were determined before and after freezing using computer-assisted sperm analysis (CASA).Plasma membrane integrity and acrosomal status were also evaluated.

Progressive motility (\%) of spermatozoa was higher $(P<0.05)$ in the semen collected during the cold period (87.1 \pm 0.6$)$ compared to that in the hot period (78.2 $\pm 0.5)$ by about $9 \%$. Period of the year had no effect on sperm curved line velocity $(V C L)$, average line velocity $(V A P)$ and straight line velocity $(V S L)(\mathrm{um} / \mathrm{sec})$. Semen samples collected during the hot period indicated a significant $(P<0.05)$ increase in the percentage of deformitive spermatozoal plasma membrane (10.9 \pm 0.7$)$ compared to the cold period $(7.9 \pm 0.6)$. Meanwhile, percentage of spermatozoa that had partial or complete acrosomal damage were higher $(P<0,05)$ in the semen collected during the hot period $(6.9 \pm 0.4$ and $2.5 \pm 0.2$, respectively) compared to the semen collected during the cold period $(5.5 \pm 0.4$ and $1.2 \pm 0.2$, respectively).

VCL, VAP and VSL were higher $(P<0.05)$ in the pre-frozen semen compared to those after $(159.7 \pm 1.3 \mathrm{vs} .72 .4 \pm 0.8 ; 83.6 \pm 0.6$ vs. $45.9 \pm 0.4$ and $68.4 \pm 0.3$ vs. $35.7 \pm 0.4$, respectively). Percentage of spermatozoa with intact plasma membrane was higher $(P<0.05)$ in pre-frozen compared to the post-frozen semen by $4 \%$. Significant increase $(P<0.05)$ was obtained in partially and completely damaged spermatozoa in the post frozen samples compared to those before freezing.

Keywords: Buffaloes, semen, freezing, season, plasma membrane integrity, acrosomal damage

\section{INTRODUCTION}

Application of artificial insemination (AI) in buffaloes is not as extensive as in cattle (FAO, 2005). The conception rate in buffalo under AI system was reported to

Issued by The Egyptian Society of Animal Production 
range between 43.4 - $60.8 \%$ (Sosa et al., 2003), due to the low percentage of viable spermatozoa after freezing (Barkawi et al., 2006), season of the year (Bhavsar et al., 1989) and/or type of extenders (Sosa et al., 2003).

Post-thawing sperm motility was found to affect fertility rate (Zhang et al., 1998; Januskauskas et al., 2001, Rasul et al., 2001, Januskauskas et al., 2003, and Rodriguez-Martinez, 2003). This is due to that semen freezing has an adverse effect on the integrity of plasma membrane and acrosome of spermatozoa (Barkawi et al., 2006). Plasma membrane plays a significant role before and during fertilization processes (Azam et al., 1998). Thus, damage of plasma membrane and / or acrosome represent the main biological factors that control acrosome reaction during fertilization process (Graham and Moce, 2005).

Studies have shown that there are significant relationships between aspects of sperm movement, cervical mucus penetration (Mortimer et al., 1990), and fertilization in vitro (Holt et al., 1985; Chan et al., 1989; and Sukcharoen et al., 1995, 1996) and in vivo (Barratt et al., 1993; Irvine et al., 1994; and Macleod and Irvine, 1995) fertilization. Computer-assisted sperm analysis (CASA) was used widely during the last two decades to determine precisely the physical characteristics of semen (Koonjaenak et al., 2007 b) and to assess the kinematics of individual spermatozoa (Budworth et al., 1987; Januskauskas et al., 1999 Mandal et al., 2003 and Hallap et al., 2004). The CASA instruments have also been used for the kinematic analysis of capacitating sperm populations to identify the proportion exhibiting hyperactivated motility.

Based on the traditional evaluation practice, many studies were conducted to evaluate the physical characteristics of Egyptian buffalo bull semen with particular reference to the season of the year (Barkawi et al., 2006 and Abdel-Khalek et al., 2008) However, no data are available describing the individual kinematics of buffalo spermatozoa.

The aim of this study was to assess the kinematics of individual buffalo bull spermatozoa and to evaluate the integrity of acrosome and plasma membrane in relation with cryopreservation process.

\section{MATERIALS AND METHODS}

\section{Animals and management:}

Six healthy and sexually matured Egyptian buffalo (Bubalus bubalis) bulls (3-5 years old) with intact testes and average body weight of $592 \pm 55 \mathrm{~kg}$ were used. The calendar of the year was divided according to environmental temperature into two periods; hot (April - August) and cold (September - March). Experimental bulls were kept tied in a semi-shaded yard, and fed on concentrate feed mixture, rice straw and green fodder according to their live body weight according to NRC (1995).

\section{Semen collection:}

The semen was collected early in the morning at the rate of two ejaculates/bull/week using an artificial vagina covered by a rubber sheath. Ejaculates were transferred immediately to the laboratory and kept in a water bath at $37^{\circ} \mathrm{C}$ until the respective examination. The outstanding ejaculates with more than $70 \%$ progressive motility $(n=140)$ were used to evaluate motion characteristics using 
Computer-Assisted Sperm Analysis (CASA) (SpermVision ${ }^{\mathrm{TM}}$ software minitube, Hauptstraße 41, 84184 Tiefenbach, Germany).

The recorded motion characteristics include: the distance curved line (DCL, microns); distance average path (DAP microns); distance straight line (DSL, microns) ; velocity curved line (VCL, Point to point velocity, microns/sec); velocity average line (VAP, point to point velocity on a path constructed using a roaming average, microns/sec) as well as, the velocity straight line spermatozoa (VSL, the average path and the point reached that is furthest from this origin during the measured time period, microns/sec).

\section{Semen processing and freezing:}

Selected semen ejaculates were diluted using Tris-based extender at a rate of 1:10 (v/v) (Osman, 1996). Diluted semen was packed into French plastic straws (0.25 ml) using an automatic machine for filling and sealing (LPE Branson generator IMV Technologies, France) and kept into the refrigerator $\left(5^{\circ} \mathrm{C}\right)$ for four hours as equilibrium period. Thereafter, straws were mounted horizontally on a metal rack placed in freezing floating boat to liquid nitrogen $\left(\mathrm{LN}_{2}\right)$ vapor. After $15 \mathrm{~min}$, the loaded straws were plunged directly into the liquid nitrogen and stored until respective evaluation.

\section{Evaluation of plasma membrane and acrosomal integrity:}

Plasma membrane integrity was determined using Hypo-Osmotic Swelling Test (HOST) according to the method described by Jeyendran et al. (1984). A minimum of 200 sperm were checked under phase contrast microscopy (400x). Sperm storage displaying different types of swelling (coiling of tails) were considered as positive for the HOST. Percentage of hypo osmotic sperm swelling was calculated as the total number of spermatozoa with coiled tails / total number of sperm (coiled and normal tails) X 100.

Assessment of acrosome status of spermatozoa was executed according to the procedure outlined by Watson (1975). The percentage of intact acrosome was calculated for 200 spermatozoa selected randomly from each slide as no. of intact spermatozoa / total number of checked spermatozoa X 100. Integrity status of spermatozoa was classified into three categories: intact (when the stain was clearly distributed over the anterior part of the sperm to the equatorial segment), partially damaged (when the stain partially covered the acrosome region) and completely damaged (sperm with acrosome completely lost) when the sperm had no acrosome.

\section{Statistical analysis:}

The data of motion characteristics were analyzed using the General Linear Model procedure (SAS, 1998) to test the effects of the period of the year (cold and hot) and freezing on the measured traits applying the following model:

$\mathrm{Y}_{\mathrm{ijkl}}=\mu+\mathrm{S}_{\mathrm{i}}+\mathrm{F}_{\mathrm{j}}+\left(\mathrm{S}_{\mathrm{i}} * \mathrm{~F}_{\mathrm{j}}\right)_{\mathrm{ijk}}+\mathrm{e}_{\mathrm{ijkl}}$

$\mathrm{Y}_{\mathrm{ijkl}}=$ The measured trait.

$\mu=$ Overall mean.

$\mathrm{S}_{\mathrm{i}}=$ Effect of period of the year $($ Cold $=1$ and Hot $=2)$. 
$\mathrm{F}_{\mathrm{j}}=$ Effect of freezing (pre freezing $=1$, post-freezing=2).

$\left(\mathrm{S}_{\mathrm{i}} * \mathrm{~F}_{\mathrm{j}}\right)_{\mathrm{ijk}}=$ the interaction between the period of the year and freezing

$\mathrm{e}_{\mathrm{ijkl}}=$ Experimental error supposed to be randomly distributed

\section{RESULTS AND DISCUSSION}

\section{Characteristics of spermatozoa kinetics: \\ Effect of period of the year:}

Total and progressive motility of spermatozoa were significantly higher $(\mathrm{P}<0.05)$ in the semen collected during the cold compared to the hot period of the year. The studied velocity traits showed non-significant difference between the two studied periods of the year (Table 1).

Table 1. Traits of sperm motility (Mean \pm SEM) in fresh semen of buffalo bulls as affected by the period of the year

\begin{tabular}{|c|c|c|}
\hline \multirow[t]{2}{*}{ Traits } & \multicolumn{2}{|c|}{ Period of the year } \\
\hline & Hot & Cold \\
\hline \multicolumn{3}{|l|}{ Motility (\%) } \\
\hline Total motility & $84.6^{\mathrm{b}} \pm 0.4$ & $91.3^{\mathrm{a}} \pm 0.5$ \\
\hline Progressive motility & $78.2^{b} \pm 0.5$ & $87.1^{\mathrm{a}} \pm 0.6$ \\
\hline \multicolumn{3}{|l|}{ Velocity types } \\
\hline$\overline{\mathrm{DAP} \text { (um) }}$ & $36.7^{\mathrm{a}} \pm 0.3$ & $37.1^{\mathrm{a}} \pm 0.4$ \\
\hline DCL (um) & $71.5^{\mathrm{a}} \pm 0.6$ & $70.5^{\mathrm{a}} \pm 0.7$ \\
\hline DSL (um) & $29.9^{\mathrm{a}} \pm 0.3$ & $30.2^{\mathrm{a}} \pm 0.4$ \\
\hline VAP (um/s) & $83.0^{\mathrm{a}} \pm 0.7$ & $84.8^{\mathrm{a}} \pm 0.8$ \\
\hline VCL (um/s) & $161.4^{\mathrm{a}} \pm 1.3$ & $160.9^{\mathrm{a}} \pm 1.6$ \\
\hline VSL (um/s) & $67.7^{\mathrm{a}} \pm 0.7$ & $69.2^{\mathrm{a}} \pm 0.8$ \\
\hline
\end{tabular}

\section{Plasma membrane and acrosomal integrity: \\ Effect of period of the year:}

Period of the year had a significant $(\mathrm{P}<0.05)$ effect on the percentage of spermatozoa with intact plasma membrane. The semen collected during the hot period of the year showed lower percentage of intact plasma membrane relative to that collected during the cold period by about 3\% (Table 3). This trend comes in agreement with the results obtained by Barkawi et al. (2006) who reported higher percentage of intact plasma membrane in buffalo bull spermatozoa collected during the cold vs the hot period.

The effect of the period of the year on the total and progressive motility comes in accordance with the findings of Barkawi et al. (2006) and Koonjaenak et al. (2007a) who reported that the hot period of the year had adverse effect of the quality of produced semen either from Egyptian or Swamp buffalo. This feature may be attributed to the low released concentrations of $\mathrm{GnRH}$ and testosterone (Younis, 1998) and / or LH basic concentration (Mandal et al., 2000) released during the hot period of the year. 
Table 2. Post-freezing sperm motility traits (Mean \pm SEM) of buffalo bull semen analyzed by computer-assisted sperm analysis (CASA) as affected by the period of the year

\begin{tabular}{|c|c|c|}
\hline Traits & Pre-freezing & Post-freezing \\
\hline \multicolumn{3}{|l|}{ Motility (\%) } \\
\hline$\overline{\text { Total motility }}$ & $87.5^{\mathrm{a}} \pm 0.4$ & $63.4^{\mathrm{b}} \pm 0.8$ \\
\hline Progressive motility & $81.9^{\mathrm{a}} \pm 0.5$ & $47.4^{b} \pm 0.8$ \\
\hline \multicolumn{3}{|l|}{ Velocity types } \\
\hline$\overline{\text { DAP (um) }}$ & $36.8^{\mathrm{a}} \pm 0.3$ & $19.4^{\mathrm{b}} \pm 0.2$ \\
\hline DCL (um) & $70.4^{\mathrm{a}} \pm 0.6$ & $30.8^{b} \pm 0.4$ \\
\hline DSL (um) & $30.1^{\mathrm{a}} \pm 0.3$ & $15.1^{\mathrm{b}} \pm 0.2$ \\
\hline VAP (um/s) & $83.6^{\mathrm{a}} \pm 0.6$ & $45.9^{b} \pm 0.4$ \\
\hline VCL (um/s) & $159.7^{\mathrm{a}} \pm 1.3$ & $72.4^{b} \pm 0.8$ \\
\hline VSL (um/s) & $68.4^{\mathrm{a}} \pm 0.3$ & $35.7^{\mathrm{b}} \pm 0.4$ \\
\hline
\end{tabular}

\section{Effect of freezing:}

Cryopreservation of semen was found to be negatively affect $(\mathrm{P}<0.05)$ all the studied traits of spermatozoal motility compared to the cryopreservation estimates pre-freezing. The percentage of motile spermatozoa and progressive motility decreased post-freezing by 24 and $35 \%$ in comparison to the values recorded prefreezing, respectively (Table 2). This result cames in agreement with that reported by Budworth et al. (1988), Mandal et al. (2000) and Barkawi et al. (2006).

The pattern of sperm motion reflects the biochemical environment and physical conditions imposed on spermatozoa. The reduction in spermatozoal motility and velocity (VCL, VSL and VAP) were most probably attributed to the percentage of injured spermatozoa during the cryopreservation process (Watson, 1995). Sperm velocity was found to reflect its mitochondrial function (Graham et al., 1984) and subsequent fertility of bulls (Budworth et al., 1988; and Kjaestad et al., 1993). The damage was mainly attributed to the formation of ice crystals (Mazur, 1984) in the mitochondria and axonemes resulting in impaired sperm motility (Courtens et al., 1989). Such changes increase the levels of intracellular calcium resulting in increased circular sperm motility (Suarez et al., 1993)

Percentage of spermatozoa that had intact acrosomes was higher $(\mathrm{P}<0.05)$ by about $2.7 \%$ in the semen samples collected during the cold period of the year compared to those collected during the hot period. On the other hand, the percentage of spermatozoa with partially damaged or completely lost acrosomes were higher in the hot period compared to the cold period by 1.4 and $1.3 \%$, respectively (Table 3 and Plates 1 and 2). 
Table 3. Effect of period of the year (mean \pm SEM) on plasma membrane and acrosomal integrity of buffalo bull spermatozoa

\begin{tabular}{|c|c|c|}
\hline \multirow[t]{2}{*}{ Traits } & \multicolumn{2}{|c|}{ Period of the year } \\
\hline & Cold & Hot \\
\hline \multicolumn{3}{|c|}{ Plasma membrane integrity (\%) } \\
\hline Intact & $92.1^{\mathrm{a}} \pm 0.6$ & $89.1^{\mathrm{b}} \pm 0.7$ \\
\hline In-intact & $7.9^{\mathrm{a}} \pm 0.6$ & $10.9^{b} \pm 0.7$ \\
\hline \multicolumn{3}{|c|}{ Acrosomal integrity (\%) } \\
\hline Intact & $93.3^{\mathrm{a}} \pm 0.4$ & $90.6^{b} \pm 0.5$ \\
\hline Partially damaged & $5.5^{\mathrm{a}} \pm 0.4$ & $6.9^{\mathrm{b}} \pm 0.4$ \\
\hline Completely lost & $1.2^{\mathrm{a}} \pm 0.2$ & $2.5^{\mathrm{b}} \pm 0.2$ \\
\hline
\end{tabular}

Means having different superscripts within each factor within the same column differ significantly at $5 \%$ level.

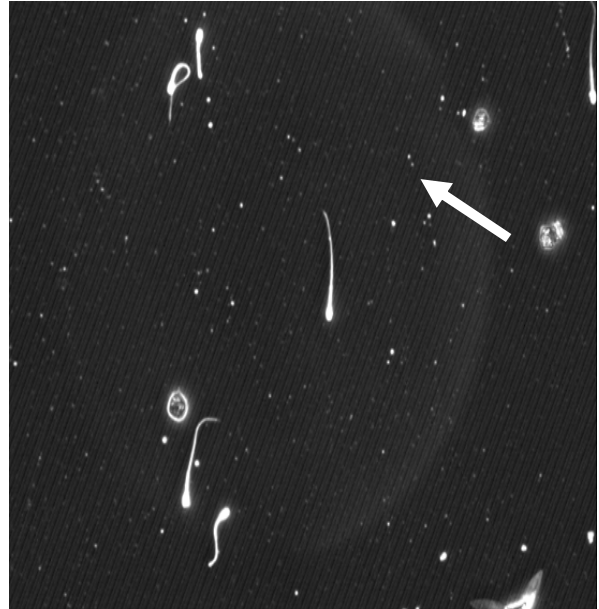

Plate 1: Buffalo spermatozoa with in-intact plasma membrane as pointed with arrow (400x).

The significant reduction in the percentage of the acrosomal integrity of buffalo spermatozoa during the hot period were in consensus with the findings of Mandal et al. (2000), who reported a similar trend.

\section{Effect of freezing:}

Percentage of spermatozoa with intact plasma membrane insignificantly $(\mathrm{P}<0.05)$ decreased in the frozen semen by about $4 \%$ compared to that recorded before freezing (Table 4). This reduction coincided with the increased incidence of spermatozoa with partial or complete damage of acrosomes $(\mathrm{P}<0.05)$ post-freezing compared to pre-freezing by 1 and $0.8 \%$, respectively, (Table 4 and Plates 3 and 4 ). 
Table 4. Effect of freezing (mean \pm SEM) on plasma membrane and acrosomal integrity of Egyptian buffaloes spermatozoa

\begin{tabular}{lcc}
\hline Traits & Pre-freezing & Post-freezing \\
\hline Plasma membrane integrity (\%) & & \\
\hline Intact & $92.6^{\mathrm{a}} \pm 0.5$ & $88.5^{\mathrm{b}} \pm 0.7$ \\
In-intact & $7.4^{\mathrm{a}} \pm 0.5$ & $11.5^{\mathrm{b}} \pm 0.7$ \\
Acrosomal integrity (\%) & & \\
\hline Intact & $92.1^{\mathrm{a}} \pm 0.6$ & $91.8^{\mathrm{a}} \pm 0.3$ \\
Partially damaged & $5.6^{\mathrm{a}} \pm 0.5$ & $6.7^{\mathrm{b}} \pm 0.3$ \\
Completely lost & $2.2^{\mathrm{a}} \pm 0.3$ & $1.4^{\mathrm{b}} \pm 0.1$
\end{tabular}

Means having different superscripts within each factor within the same column differ significantly at $5 \%$ level.

The obtained percentage of spermatozoa with intact plasma membrane was higher than those obtained by Azam et al. (1998), Koonjaenak et al. (2007a) and Selvaraju et al. (2008) in Surti buffalo bulls.

The decrease in the incidence of post-frozen intact spermatozoa was most probably due to the destabilization of plasma membrane during cryopreservation process when exposed to low temperature and high salt concentration (Holt and North, 1994 and Shannon and Vishwanath, 1995). This phenomenon was reported to be associated with the loss of plasma-lemma over the entire acrosome, a marked projection in the anterior part of outer acrosomal membranes, and extensive vesiculation and disruption of plasma-lemma and outer acrosomal membranes (Krogenaes et al., 1994).

The recorded post-freezing percentage of spermatozoa with intact acrosomes $(91.0 \%)$ was higher than the values reported previously by Singh et al. (1989); Aguiar et al. (1994); Kumar et al. (1993) and Barkawi et al. ( 2006) (81.9 - 90\%). However, there is a common agreement among them that cryopreservation of semen has an adverse effect on the integrity of spermatozoa.

The recorded percentage of the spermatozoa with intact acrosome before freezing is lower than the value reported by Krishna and Rao (1987) in Murrah buffalo bulls $(93.5 \%)$. The obtained percentage of post-frozen intact spermatozoa $(91.8 \%)$ in this study was higher than the values found by Ismail (1993); Osman (1996); Barkawi et al. (2006) and Abdel-Khalek et al. (2008) in Egyptian buffalo bulls and Azam et al. (1998); Pratap et al. (2000); Panghal et al. (2002) and Maurya et al .(2003) in Murrah buffalo bulls and Selvaraju et al. (2008) in Surti buffalo bulls. They recorded percentage from 11.5 to $73.5 \%$. Meanwhile, it was lower than the percentages reported by Sosa et al. (2003) for Egyptian buffalo bulls (93.9 \%) and Koonjaenak et al. (2007a) for Swamp buffalo bulls $(98.9 \%)$. 


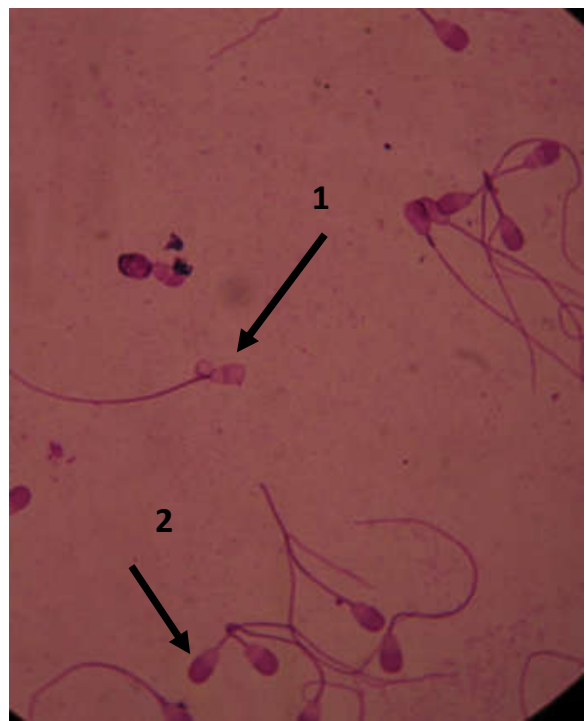

Plate 3: Buffalo spermatozoa with completely lost acrosomes (1) as compared to intact one (2) $(1000 x)$.

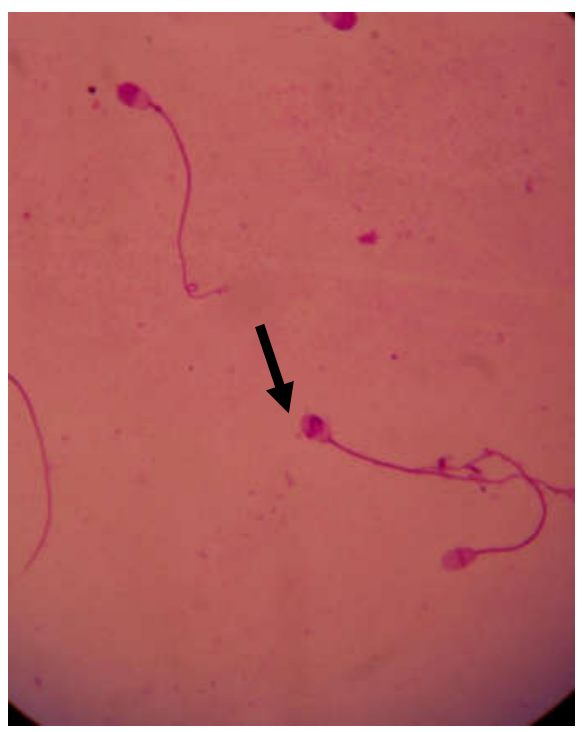

Plate 4: Buffalo spermatozoa with partially damaged acrosomes as pointed with arrow (1000x).

\section{ACKNOWLEDGMENT}

The authors would like to acknowledge the Cattle Information System/Egypt (CISE), Faculty of Agriculture, Cairo University for financing this work throughout providing animals and lab preparations.

\section{REFERENCES}

Abdel-Khalek A.E., M.B. Aboul-Ela, S. A. Fawzy, and E. Dandooush, 2008. Semen quality of Holstein and buffalo bulls after filtration using Sephadex Column. Saudi J. Biol. Sci., 15: 91-97

Aguiar P.H.P., V.J., Andrade, J.J. Abreu, and N.B.N. Gomez, 1994. Physical and morphological semen characteristics of buffaloes aged from four to eight years old. Proc. $4^{\text {th }}$ Int. Buffalo Congr., Sao Paulo, Brazil , 3: 486-488

Azam M., M. Anzar, and M. Arslan, 1998. Assessment of post-thaw semen quality of buffalo and Sahiwal bulls using new semen assays. Pakistan Vet. J., 2: 74-80.

Barkawi A.H., G. Ashour, Y.M. Hafez, S.A. Ibrahim, A.K. El-Asheeri, and Sh.M. Desoky, 2006. Plasma membrane integrity and acrosomal damage of Egyptian buffalo (Bubalus bubalis) spermatozoa in relation to period of the year, freezing and type of extender. Buffalo J., 2: 143-153

Barratt C.L.R., M.J. Tomlinson, and I.D. Cooke, 1993. Prognostic significance of computerized motility analysis for in vivo fertility. Fertil. Steril., 60: 520-525.

Bhavsar B. K., A. J. Dhami, and S. B. Kodagali, 1989. Monthly variations in freezability and fertility of Mehsana buffalo semen. Indian J. Dairy Sci., 42: 246250 . 
Budworth P. R., R.P. Amann, and P. L. Chapman, 1988. Relationships between computerized measurements of motion of frozen-thawed bull spermatozoa and fertility. J. Androl., 9:41-54.

Budworth P.R., R.P. Amann, and R.H. Hammerstedt, 1987. A microcomputerphotographic method for evaluation of motility and velocity of bull sperm. J. Dairy Sci., 70:1927-1936.

Chan S.Y.W., C. Wang, and M. Ng, 1989. Evaluation of computerized analysis of sperm movement characteristics and differential sperm tail swelling patterns in predicting human in vitro fertilizing capacity. J. Androl., 10: 133-138.

Courtens J. L., H. Ekwall, M. Paquignon, and L. Ploen, 1989. Preliminary study of water and some element contents in boar spermatozoa, before, during and after freezing. J. Reprod. Fertil., 87: 613-626.

FAO, 2005. Food and Agriculture Organization of the United Nations. FAOSTAT online statistical service. FAO. http://www.fao.org.

Graham E. F., M. K. L. Schmehl, and R. C. M. Deyo, 1984. Cryopreservation and fertility of fish, poultry and mammalian spermatozoa. Proc. of the $10^{\text {th }}$ NAAB Tech. Conf. on Artificial Insemination and Reprod, NAAB, 4-24.

Graham J.K. and E. Moce, 2005. Fertility evaluation of frozen-thawed semen. Theriogenology 64: 492-504.

Hallap T., M. Haard, U. Jaakma, B. Larsson, and H. Rodriguez-Martinez, 2004. Does cleansing of frozen-thawed bull semen before assessment provide samples that relate better to potential fertility? Theriogenology, 62: 702-713.

Holt W.V. and R. D. North, 1994. Effects of temperature and restoration of osmotic equilibrium during thawing on the induction of plasma membrane damage in cryopreserved ram spermatozoa. Biol. Reprod., 51: 414-424

Holt W.V., H.D.M. Moore, and S.G. Hillier, 1985. Computer-assisted measurement of sperm swimming speed in human semen: correlation of results with in vitro fertilization assays. Fertil. Steril., 44: 112-119.

Irvine D.S., I.C. Macleod and A.A. Templeton, 1994. A prospective clinical study of the relationship between the computer-assisted assessment of human semen quality and the achievement of pregnancy in vivo. Hum. Reprod., 9: 2324-2334.

Ismail T.I.M., 1993. Studies on thawing of frozen buffalo semen. Ph.D. V. Sc. Thesis, Fac. Vet. Med., Cairo Univ.

Januskauskas A., J. Gil, L. Soderquist, M. G. Haard, and M. C. Haard, 1999. Effect of cooling rates on post-thaw sperm motility, membrane integrity, capacitation status and fertility of dairy bull semen used for artificial insemination in Sweden. Theriogenology, 52: 641-58.

Januskauskas A., A. Johannisson, and H. Rodriguez-Martinez, 2001. Assessment of sperm quality through fluorometry and sperm chromatin structure assay in relation to field fertility of frozen-thawed semen from Swedish AI bulls. Theriogenology, 55: 947-961.

Januskauskas A., A. Johannisson, and H. Rodriguez-Martinez, 2003. Subtle membrane changes in cryopreserved bull semen in relation with sperm viability, chromatin structure, and field fertility. Theriogenology; 60: 743-58. 
Jeyendran R. S., H. H. Van der Ven, M. Perez-Pelaez, B. J. Craboand, and L.J.D. Zaneveld, 1984. Development of an assay to assess the functional integrity of the human sperm membrane and its relationship to other semen characteristics. J.Reprod. Fertil. 70: 219-228.

Kjaestad H., E. Ropstad, and K. A. Berg, 1993 Evaluation of spermatological parameters used to predict fertility of frozen semen. Acta Vet. Scand., 34: 299303.

Koonjaenak S., V. Chanatinart, S. Aiumlamai, T. Pinyopumimintr, and H. Rodriguez-Martinez, 2007a. Seasonal variation in semen quality of swamp buffalo bulls (Bubalus bubalis) in Thailand Asian J. Androl., 1: 92-101

Koonjaenak S., P. Pongpeng, S. Wirojwuthikul, A. Johannisson, A. Kunavongkrit and H. Rodriguez-Martinez, 2007b. Seasonality affects post-thaw plasma membrane intactness and sperm velocities in spermatozoa from Thai AI Swamp buffaloes (Bubalus bubalis) Theriogenology, 67: 1424-1435

Krishna M. K. and R. A. Rao, 1987. Acrosomal morphology in fresh and freezethawed buffalo sperm. Indian Vet. J., 3: 248-249.

Krogenaes A., B. K. Anderson, A. 1. Hafne, and E. Engeland, 1994. Membrane alterations in bull spermatozoa after freezing and thawing and after in vitro fertilization. Acta Vet. Scand., 35:17-26.

Kumar S., K. L. Sahni, and G. S. Bistha, 1993. Cytomorphological characteristics of motile and static semen of buffalo bulls. Buffalo J., 2: 117-127.

Macleod I.C. and D.S. Irvine, 1995. The predictive value of computer-assisted semen analysis in the context of a donor insemination programme. Hum. Reprod., 10: 580-586.

Mandal D. K., P. K. Nagpaul, and A. K. Gupta, 2000. Seasonal variation in seminal attributes and sexual behaviour of Murrah buffalo bulls.Indian J. Dairy Sci., 4 : 278-283

Mandal D. K., P. K. Nagpaul, and A. K. Gupta, 2003. Motion characteristics of Murrah buffalo bull spermatozoa in various seasons and its relationship with functional integrity of the plasmallema. Theriogenology; 60: 349-358.

Maurya V. P., R. K. Tuli, and P. Singh, 2003. Effect of filtration on freezability and acrosomal integrity of Murrah buffalo bull semen .Indian J. Anim. Sci., 73: 983985.

Mazur P., 1984. Freezing of living cells: mechanisms and implications. Am. J. Physiol. 247:125-142.

Mortimer, D., S.T. Mortimer, M.A. Shu, and R. Swart, 1990. A simplified approach to sperm-cervical mucus interaction using a hyaluronate migration test. Hum. Reprod., 5: 835-841.

NRC, 1995. National Research Council, $6^{\text {th }}$ Ed. Nutrient requirements of cattle. National Academy Press, Washington DC, USA.

Osman K.T., 1996. Some reproductive aspects of Egyptian buffalo bulls. Ph.D. Thesis, Fac. Agric., Ain-Shams Univ., Cairo, Egypt.

Panghal V. S., R. K. Tuli, and R. Goyal, 2002. Influens of thawing temperature on sperm survivability of buffalo semen frozen after filteration through sephadex column. Indian J. Dairy Sci., 4: 211-213.

Pratap N., V. N. Vishwanatha Reddy, P.A. Sarama, and T. G. Honnappa, 2000. Employment of the hypoosmotic swelling test (HOST) to evaluate sperm 
membrane integrity of fresh and frozen buffalo (Bubalus Bubalis) bull semen. Buffalo J., 2: 207-213.

Rasul Z., N. Ahmad, and M. Anzar, 2001. Changes in motion characteristics, plasmamembrane integrity, and acrosome morphology during cryopreservation of buffalo spermatozoa. J. Androl., 22: 278-283.

Rodriguez-Martinez H., 2003. Laboratory semen assessment and prediction of fertility: still utopia? Reprod. Domest. Anim., 38: 312-318.

SAS, 1998. SAS User's Guide, SAS Institute Inc., Cary, NC., USA

Selvaraju S., J.P. Ravindra, J. Ghosh, P.S.P. Gupta, and K.P. Suresh, 2008. Evaluation of sperm functional attributes in relation to in vitro sperm-zona pellucida binding ability and cleavage rate in assessing frozen thawed buffalo (Bubalus bubalis) semen quality. Anim. Reprod. Sci., 106: 311-321

Shannon P. and R. Vishwanath, 1995. The effect of optimal and suboptimal concentrations of sperm on the fertility of fresh and frozen bovine semen and a theoretical model to explain the fertility differences. Anim. Reprod. Sci., 39:1-10.

Singh N. P., R. S. Manik, and V. S. Raina, 1989. Effect of cysteine fortification on preservability of buffalo semen in milk whey extenders. Theriogenology, 32: 979986.

Sosa G. A., E. D. El-Deeb, and K. M. El-Sabragh, 2003. Interaction of diluents, cryoprotective agents and straw filling capacity on quality and freezing ability of buffalo semen.Vet. Med. J. Giza, 4: 553-566.

Suarez S. S., S.M. Varosi, and X. B. Dai, 1993. Intracellular calcium increases with hyperactivation in intact moving hamster sperm and oscillates with the flagellar beat cycle. Proc. Natl. Acad. Sci., USA, 90:4660-4664.

Sukcharoen N., J. Keith, D.S. Irvine, and R.J. Aitken, 1995. Predicting the fertilizing potential of human sperm suspensions in vitro: Importance of sperm morphology and leukocyte contamination. Fertil. Steril., 63: 1293-1300.

Sukcharoen N., J. Keith, D.S. Irvine, and R.J. Aitken, 1996. Prediction of the in-vitro fertilization (IVF) potential of human spermatozoa using sperm function tests: the effect of the delay between testing and IVF. Hum. Reprod., 11: 1030-1034.

Watson P.F., 1995. Recent developments and concepts in the cryopreservation of spermatozoa and the assessment of their post-thawing function. Reprod. Fertil. Dev., 7: 871-891.

Watson P.F., 1975. Use of a giemsa stain to detect changes in acrosomes of frozen ram spermatozoa. Vet. Rec., 5: 12-15.

Younis M., H. A. Samad, A. Nazir and I. Ahmed, 1998. Studies on semen quality of young, adult and old buffalo bulls during low and peak breeding seasons. Pakistan Vet. J., 18: 134-140.

Zhang B.R., B. Larsson, N. Lundeheim and H. Rodriguez-Martinez, 1998. Sperm characteristics and zona pelluzida binding in relation to field fertility of frozenthawed semen from dairy AI bulls, Int. J. Androl., 21: 207-216. 
تأثير الموسم والتجميد على حركة وسلامة الفثاء البلازمى وحالة الأكروسوم فى الحيوانات المنوية للجاموس المصرى عرئ

شريف محمد دسوقى ', جمال عاشور ' , أحمد محمد حننين ب, أشرف هشام برقاوى '

ا ـ قسم الإتتاج الحيوانس, كلية الزراعة, جامعة القاهرة، ب ـ قسم الإنتاج الحيوانس, كلية الزراعة, جامعة قناة. السويس

استهدفت هذه الدراسة دراسة تاثير موسم السنة والحفظ بالتجميد على الحيوانات المنوية للجاموس

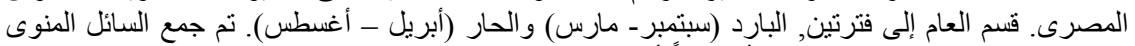

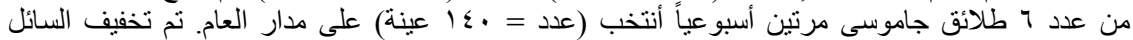

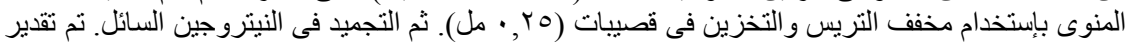

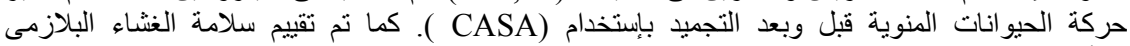
و الأكروسوم للحيو انات المنوية.

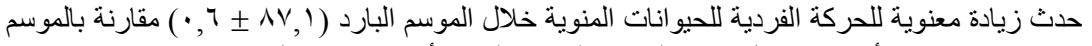

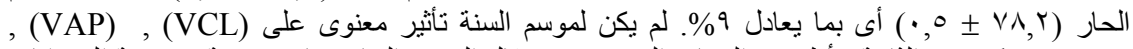

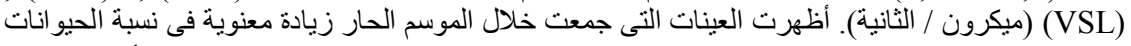

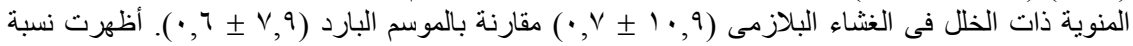

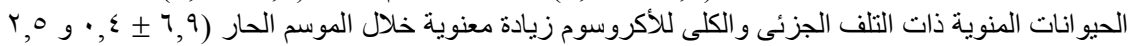

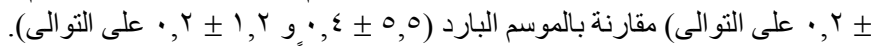

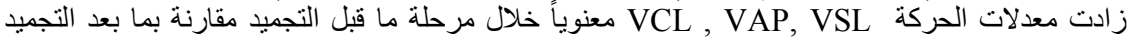
( $109, \gamma)$

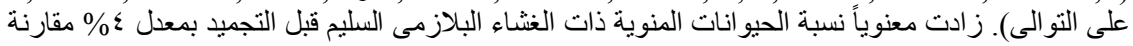

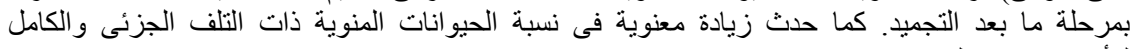

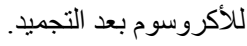

